\title{
Patterns of Routine Antenatal Laboratory Test Results at Booking in Enugu State University Teaching Hospital, Enugu, Southeast Nigeria
}

\author{
Innocent IgwebuezeOkafor ${ }^{*}$, Boniface UwaezuokeOdugu ${ }^{1}$, \\ EdmundOnyemaechiNdibuagu ${ }^{2}$ \\ ${ }^{1}$ Department of Obstetrics and Gynecology, Enugu State University of Science of Technology/Teaching \\ Hospital, Enugu; Nigeria \\ ${ }^{2}$ Department of Community Medicine, Enugu State University of Science and Technology /Teaching Hospital, \\ Enugu; Nigeria \\ ${ }^{* 1}$ Corresponding author: Innocent IgwebuezeOkafor. Email: okaforii@yahoo.com
}

Phone: +2348034006918

\begin{abstract}
Objectives: To determine the patterns of routine antenatal care laboratory test results at booking in Enugu State University Teaching Hospital (ESUTH), Enugu, and to review the literature on the subject.

Methods: The registers for the results of routine laboratory tests at booking in ESUTH, Enugu were reviewed from April 1, 2014 to August 31, 2016. Data on age, blood group, rhesus status, hemoglobin genotype, packed cell volume; human immunodeficiency virus screening (HIV), venereal disease research laboratory (VDRL) and hepatitis B virus surface antigen (HBsAg) tests at booking were collected and analyzed with Excel 2007 software. The results were presented in tables, percentages and graphs.
\end{abstract}

Results: A total of 5293 mothers were tested; $2706(51.12 \%)$ and $2500(47.23 \%)$ of them were of ages $<30$ and 30-40 years respectively (Table 1). Table 2 showed the commonest blood group was ' $\mathrm{O}$ ' 3062(57.85\%). Most of the mothers $4811(90.89 \%)$ were Rhesus D positive while $482(9.11 \%)$ of them were negative. Hemoglobin genotype results were: AA 4066(76.82\%), AS 1217(22.99\%), and SS 8(0.15\%). About 3819(72.15\%) had packed cell volume of $31 \%$ and above. Table 3 revealed $232(4.83 \%)$ women tested positive to HIV, but $17(0.32 \%)$ only were new cases. Twenty eight $(0.53 \%)$ women were reactive to VDRL while $166(3.14 \%)$ tested positive to HBsAg test. Many women 5061(95.62\%) and 5127(96.86\%) tested negative to HIV and HBsAg tests respectively.

Conclusion: Most women are young ( $<40$ years), have blood group O rhesus D positive, hemoglobin AA genotype, and are not anemic at booking. Many women are non-reactive to VDRL, HIV and HBsAg tests; and are vulnerable to infections. The marked reductions on SS genotype, VDRL and HIV new cases in this study have justified the critical preventive role of routine ANC laboratory tests in our current obstetric practice and the need for the continuation of the practice.

Key words: Patterns, Routine ANC Tests, Booking, ESUTH, Enugu, Literature Review.

\section{INTRODUCTION}

Antenatal care (ANC) is an integral part of a continuum of evidence-based, preventive, cost-effective, and low-technology healthcare interventions during pregnancy, childbirth, and postnatal periods with the aim to ensure healthy maternal, fetal, newborn and infant outcomes [1]. Such quality ANC interventions should reduce or prevent approximately the 303000 maternal deaths and 2.6 million stillbirths that occurred in 2015 [2, 3, 4]. Ninety nine percent of these preventable deaths occur in low-resource settings. The interventions and strategies to improve reproductive, maternal, newborn and child health are closely related and should be provided as a continuum of integrated service delivery that synergizes efficiency, and avoid duplication of resources [5]. What matters to women is that the ANC services they receive should ensure that the mother and the unborn baby are healthy; and that women have positive pregnancy experiences that transit to safe delivery of healthy babies without abuse and disrespect to them [6,7]. ANC also ensures that there are birth and emergency preparedness plans, and functional referral linkages to emergency obstetric care services [8]. These important plans are made in advance by every pregnant woman to avoid 'fatal' obstetric delays when life-threatening obstetric emergency occurs. The preventions of many prevalent health problems in developing countries such as malaria, tetanus, 
syphilis, human immunodeficiency virus (HIV), hepatitis B virus, and anemia are integrated into routine ANC services. ANC has also become the entry points for many other interventions like health promotions, early healthcare-seeking behaviors, community mobilization for financial supports, discouragement of harmful traditional practices, and referral linkages to family planning, child immunization, genital cancer screening, infertility and other reproductive health problems. Routine laboratory tests at booking are part of this gamut of evidence-based interventions to ensure healthy mothers and infants. The prevailing health challenges and the available laboratory tests appear to be the determinants of what should be included in the routine antenatal laboratory tests. The tests should be cost effective. The usual recommended routine ANC laboratory tests in low resource countries include: Packed Cell Volume (PCV), Blood/Rhesus group, Hemoglobin genotype, Veneral Disease Research Laboratory (VDRL), Human Immunodeficiency Virus (HIV), Hepatitis B (HBsAg), and urinalysis. In developed world several other investigations like full blood count; rubella antibody test, urine culture, and ultrasonography are included in the booking investigations.

Most previous studies on the subject centered on syphilis and whether the test (VDRL) should be continued as routine laboratory test in current obstetric practice $[9,10]$. Few studies in this study area have reviewed holistically routine antenatal laboratory tests as we did in this work. The objectives of the study are to determine the patterns or results of the various routine ANC laboratory tests at booking in Enugu, and to review the literature on the subject.

\section{SETTINGS AND METHODS}

Enugu State University Teaching Hospital (ESUTH) Enugu is a state owned health institution that evolved from Nursing Home in 1930 for the colonial masters to a teaching hospital status in June 2006 [11]. It is located in the center of Enugu metropolis and most of the population are Christians and of the Igbo tribe [12]. The department of Obstetrics and Gynecology in ESUTH has two professors, a reader, 8 consultants, 9 senior registrars, 13 registers, house officers, and 45 staff nurse midwives. The obstetric unit has 42 beds with an average of 2000 ANC bookings and 1250 deliveries annually. The booking antenatal clinic is on Thursdays and is conducted by two registrars and five midwives. Health education, HIV group counseling and testing, and information on other routine laboratory tests are done. Prior to the laboratory testing, the women were counseled on the benefits of the tests, the implications of both a positive or negative result, and verbal consent (or decline) obtained. The results are carried out the same day by laboratory scientists attached to the departmental side laboratory, and the results are released to the mothers by the midwives after recording the results in the registers. The registers were reviewed from April 1, 2014 to August 31, 2016. Data on age, blood group, rhesus status, hemoglobin genotype, packed cell volume; retroviral screening (HIV), venereal disease research laboratory (VDRL) and hepatitis B virus surface antigen ( $\mathrm{HBsAg}$ ) tests at booking were collected and analyzed with Excel 2007 software. The results were presented in tables, percentages and graphs.

\section{RESULTS}

A total of 5293 mothers gave consent and were tested; 2706 (51.12\%) and $2500(47.23 \%)$ of them were of ages $<30$ and $30-40$ years respectively as in Table 1 . Only $82(1.55 \%)$ women were more than 40 years. Table 2 showed the commonest blood group was 'O' 3062(57.85\%) while 'AB'114(2.15\%) was rare. Most of the mothers $4811(90.89 \%)$ were Rhesus D positive while $482(9.11 \%)$ of them were negative. Hemoglobin genotype results were: AA 4066(76.82\%), AS 1217(22.99\%), and SS 8(0.15\%). About 3819(72.15\%) had packed cell volume of $31 \%$ and above. However, about 1474(27.85\%) women booked with mild to moderate anemia. Table 3 revealed 232(4.83\%) women tested positive to HIV, but $17(0.32 \%)$ only were new cases. Twenty eight $(0.53 \%)$ women were reactive to VDRL while $166(3.14 \%)$ tested positive to HBsAg test. Many women 5061(95\%) and 625127(96.86\%) were non-reactive to HIV and HBsAg tests respectively, and are vulnerable to infections. The summaries of the results are presented graphically in Figures 1 and 2.

\section{DISCUSSION AND CONCISE LITERATURE REVIEW ON THE TESTS Blood group and Rhesus types}

Generally, it is very importance to know your blood group and rhesus status to prevent the risk of incompatible blood transfusions and reactions during emergencies; rhesus D sensitization and hemolytic disease of the new born in future rhesus- $\mathrm{D}$ positive baby pregnancies. The prevalence of blood groups among antenatal women in Enugu were: A (23.92\%), O (57.85\%), B (16.08\%) and AB (2.15\%). This study results were similar to the results of a prospective study in Port Harcourt, South-South, Nigeria that showed blood groups of: A (26.67\%), O (52.78\%), B (18.33\%), and AB (2.22\%) [13]. Our results vary widely when compared with values from Western Europe of blood groups: A ( 42\%), O (46\%),B(9\%), and $\mathrm{AB}(3 \%)$, and South-Western Germany: $\mathrm{A}(43.26 \%), \mathrm{O}(41.2 \%), \mathrm{B}(10.71 \%)$, and $\mathrm{AB}(4.82 \%)[14,15]$. Majority of the women in our obstetric population are of blood group $\mathrm{O}$, and this knowledge is very important during dire obstetric emergencies and blood 
Prevalence of Routine Antenatal Laboratory Tests at Booking in Enugu State University of ..

transfusions. The common group $\mathrm{O}$ in this obstetric population provides an advantage in terms of availability of blood for transfusion as blood group $\mathrm{O}$ can be transfused to $\mathrm{A}, \mathrm{B}$ and $\mathrm{AB}$ after cross matching.

The result of rhesus D status in this study showed that $90.89 \%$ of the mothers were rhesus D positive while $9.11 \%$ were negative. The $9.11 \%$ rhesus D negativity in this study is higher than $4.5 \%$ in University of Nigeria Teaching Hospital, Enugu and $7.1 \%$ in Sokoto Nigeria [16, 17]. In most Caucasian population, the incidence of rhesus D negativity is $15-16 \%$, and less than $1 \%$ among Chinese and Japanese populations. In blacks, the incidence ranges from 4 to $8 \%$ [18].

Though, the risks of rhesus D iso-immunization and perinatal mortality are rare in the study population [19], health facilities managing rhesus D negative pregnancies should be able to demonstrate feto-maternal hemorrhage in the laboratories and give correct quantity of anti-D immunoglobin prophylaxis within 72 hours of any potentially sensitizing events during pregnancy and childbirth. Universal access to prophylactic anti-D should be provided for all rhesus D negative women after miscarriages,amniocentesis, cordocentesis, antepartum haemorrhage, vaginal bleeding during pregnancy, external cephalic version, abdominal trauma, intrauterine death and stillbirth, in utero therapeutic interventions, and therapeutic termination of pregnancy. The rhesus blood group of all babies delivered by rhesus D negative mothers should be determined at delivery and if found to be rhesus D positive; feto-maternal-hemorrhage testing (Kleihauer or flow cytometry test) should be carried out to estimate the quantity of fetal red cells that may have entered the maternal circulation to facilitate the administration of optimal quantity of anti-D immunoglobulin to prevent hemolytic disease of the new born.

\section{Hemoglobin genotype}

Hemoglobinopathies are common genetic disorders worldwide. They are inherited as autosomal recessive disorders from healthy-carriers. The distribution of hemoglobin genotype in this study revealed HbAA $78.82 \%$, HbAS $22.99 \%$ and $\mathrm{HbSS} 0.15 \%$. Umoh and coworkers [20] reported similar results in a mixed population of males and females as follow HbAA 78.7\%, Hb AS 19.6\%, and $\mathrm{HbSS} 1.5 \%$. HbAC and $\mathrm{HbSC}$ accounted for $0.2 \%$ and $0.04 \%$ respectively in the study. In Port Harcourt the results of hemoglobin genotypes were also similar to findings in our study with $70.00 \%$ for $\mathrm{HbAA}, 29.44 \%$ for $\mathrm{HbAS}$ and $0.56 \%$ for $\mathrm{HbSS}$. $\mathrm{HbAC}$ and HbSC did not occur in the Port Harcourt study as in our study population [13]. Geographic distribution of sickle cell disease revealed $1-10 \% \mathrm{HbSS}$ [21]. The vigorous campaign for premarital hemoglobin genotype tests and the discouragement of AS/AS or SS/SS marriages appear to be the reason for the very low HbSS in our study. Pregnancy in HbSS patient is a high risk one that is associated with many adverse outcomes. Anemia in pregnancy $(\mathrm{Hb}<11 \mathrm{~g} / \mathrm{dl})$ was reported in $94.2 \%$ of such HbSS pregnancies [22]. The high risk HbSS pregnancies should ideally be managed by experts in tertiary health institutions to reduce adverse outcomes and prevent mortalities.

\section{Packed cell volume and anemia}

About $72.15 \%$ of the women in this study had packed cell volume of $31 \%$ and above while $27.85 \%$ of them had mild to moderate anemia. The rate anemia at booking in our work was less than $54.5 \%$ reported in Uyo Nigeria where the commonest cause was iron deficiency anemia [23]. Women need to be economically empowered, encouraged to book for antenatal care, be on intermittent prophylaxis for malaria, sleep under insecticide treated net and on hematinic supplementation to prevent anemia and its complications in pregnancy. The HbAS pregnant women should be screened and treated for urinary tract infections to avoid asymptomatic bacteria, preterm delivery and anemia in pregnancy.

\section{Human immunodeficiency virus (HIV)}

HIV prevalence among pregnant women attending ANC has remained the principal data source to inform trends in generalized HIV epidemics in developing countries [24]. In Abuja, Nigeria HIV prevalence among pregnant women attending ANC ranged from $4.5 \%$ in 2005 to $11.2 \%$ in 2006 and peaked at $15.4 \%$ in 2009 [24]. A pooled study on recent HIV prevalence trends among pregnant women and all women in subSaharan Africa countries revealed that HIV prevalence declined among pregnant women from $6.5 \%$ between 2003--2008 to 5.3\% between 2009-2012; but remained unchanged among all women aged 15-49 years at 8.4\% over 10 years [25]. The HIV prevalence in ESUTH, Enugu was 4.38\%, and this is within the 4-6\% HIV prevalence for Enugu state as at 2013 [26]. The routine HIV testing of antenatal women and the freely available highly active antiretroviral therapy (HAART) for all HIV positive mothers on WHO option B+ basis [27] may be responsible for this decline. The fact that only $0.53 \%$ cases of new HIV occurred during this study period showed the critical role of ANC can play in preventing prevalent health problems like HIV. In Option B+ all HIV-positive pregnant women are commenced on a single-pill fixed-dose HAART regimen containing tenofovir, lamivudine and efavirenz from diagnosis and continued for life. Option B+ regimen is a simplified first-line antiretroviral treatment regimen that paved the way for public health approach in global scale-up of the 
use of HAART in prevention of mother-to-child transmission of HIV and elimination of paediatric HIV, and in the 'treatment as prevention of HIV' (TasP) in the prevention of new HIV infections. The crucial role of ANC in virtual elimination of mother-to-child transmission of HIV has been documented by Okafor et al [28].

\section{Venereal Disease Research Laboratory (VDRL) test}

Syphilis is systemic disease caused by Treponemapallidum. The first epidemic occurred in the 15 th century in Western Europe. It is transmitted through sexual activity from muco-cutaneous lesions. In pregnancy, mother-to-child transmission can occur through the placenta and during childbirth. Syphilis in pregnancy is an important cause of adverse feto-maternal outcomes [29]. It can cause spontaneous abortion, stillbirth, non-immune hydrops, intrauterine growth restriction, perinatal death, and serious sequel in live born infected children. Complications in the surviving newborns include deafness, multiple skin, bone, and joint deformities and haematological disorders. World health organization (WHO) recommended serological test for syphilis in pregnancy, and the treatments with injectable penicillin for the infected mothers and their partner/s to interrupt further transmission of the disease [30]. Venereal Disease Research Laboratory (VDRL) test is the most widely used screening test for syphilis, but it has a high false-positive rate of $73.3 \%$ [10]. Ideally, positive VDRL results should be confirmed with other specific tests like Treponemapallidumhaemagglutination and Fluorescent Treponemal Antibody Absorbed (FTA-ABS) test before treatment. The low prevalence of $0.53 \%$ sero-positivity in this work showed how effective ANC intervention can help in prevention of reproductive health problems. Our result is within $0.6 \%-2.3 \%$ reported rates in Nigeria for over 40 years [31-33]. However, the seropositive rates in otherAfrica countries range from $3 \%-18 \%$, and thus syphilis has remained a major problem in many countries of sub-Saharan Africa [34-36]. It is still necessary to continue the antenatal VDRL test in the developing countries until the disease is eradicated.

\section{Hepatitis B surface antigen (HBsAg)}

Hepatitis B virus (HBV) is a blood borne and sexually transmitted hepadnavirus that causes acute and chronic hepatitis, cirrhosis and hepatocellular carcinoma. It was first described in the $5^{\text {th }}$ century, but the earliest recognized outbreak occurred in Germany in 1883 after small pox vaccines prepared from human lymph were administered in 1289 shipyard workers, and 191 (15\%) developed jaundice after several weeks; but jaundice did not occur among unvaccinated workers [37] The virus is transmitted through contact with the HBV infected blood or other body fluids like serum, semen, vaginal secretion and saliva. It is stable and infectious at room temperature environment even after 7 days. An estimated 240 million people are chronically infected with hepatitis B (HBsAg positive > 6 months), and more than 686000 people die annually due to its complications [38].Perinatal transmission, infants, and children under 5 infections with immature immune systems account for $90 \%$ of chronic HBV infections while $95 \%$ of adult infections recover fully [39-41]. Chronic hepatits B also occur also in immunosuppressed persons [42]. Horizontal transmission occurs when susceptible individuals and households come in contact to infected blood, and body fluids. Unimmunized individuals, children, injection drug users, people practicing unsafe sex, and health workers are at risk of infection. The progression of chronic HBV infection to cirrhosis and hepatocellular carcinoma can be prevented with antiviral drugs, and new infections are also preventable with safe and effective vaccine.

Baruch Samuel Blumberg in 1964, discovered hepatitis B surface antigen (HBsAg) in the blood of an Australian hemophiliac who had multiply blood transfusions that is used as screening test for the virus during ANC $[43,44]$. HBV infection is hyperendemic (> 8\% HBsAg chronic carriers in the general population) in some sub-Saharan countries such as Nigeria, Namibia, Gabon, Cameroon, Burkina Faso. Kenya, Zambia, Ivory Coast, Liberia, Sierra Leone and Senegal are considered areas of intermediate endemicity (2\%-8\%), while Egypt, Tunisia, Algeria and Morocco, located in the north of the continent, show a low endemicity level $(<2 \%)[45]$. Pooled prevalence results of HBV in Nigeria from 2000-2013 studies showed: $14.0 \%$ for blood donors; $14.1 \%$ for pregnant women attending antenatal clinics; and 11.5\% for children [46]. Other studies in Niger Delta and Benin reported seroprevalence of HBsAg among pregnant women of 5.3\% and 6.6\% respectively [47, 48]. The seroprevalence of $3.14 \%$ in our study is lower than other studies in Nigeria. May be increase in awareness, acceptance of universal HBV vaccine at birth and in susceptible individuals may explain the low seroprevalence in this study.

\section{CONCLUSION}

Most women are young ( $<40$ years), have blood group O rhesus D positive, hemoglobin AA genotype, and are not anemic at booking. Many women are non-reactive to VDRL, HIV and HBsAg tests; and are vulnerable to infections. The marked reductions on the prevalence of SS genotype, VDRL and HIV new cases in this study have justified the critical preventive role of routine ANC laboratory tests in our current obstetric practice and the need for the continuation of the practice. The inclusions of the laboratory diagnoses of other 
common health problems like malaria and diabetes mellitus in routine ANC services in Nigeria are recommended.

Table 1: Ages of mothers at booking antenatal clinic in ESUTH*, Enugu

$\begin{array}{llr}\text { Age in years } & \text { Number } & \text { Percentage (\%) } \\ <30 & 2706 & 51.12 \\ 30-40 & 2500 & 47.23 \\ >40 & 82 & 1.55 \\ \text { Not states } & 0 & 0 \\ \text { Total } & 5293 & 99.9\end{array}$

ESUTH* $^{*}=$ Enugu State University Teaching Hospital

Table 2: Results of hematological tests at booking antenatal clinic in ESUTH*, Enugu

$\begin{array}{llc}\text { Blood group } & \text { Number } & \text { Percentage }(\%) \\ \text { A } & 1266 & 23.92 \\ \text { O } & 3062 & 57.85 \\ \text { B } & 851 & 16.08 \\ \text { AB } & 114 & 2.15 \\ \text { Not stated } & 0 & 0 \\ \text { Total } & 5293 & 100 \\ \text { Rhesus status } & & \\ \text { Positive } & 4811 & 90.89 \\ \text { Negative } & 482 & 9.11 \\ \text { Not stated } & 0 & 0 \\ \text { Total } & 5293 & 100 \\ \text { Haemoglobin genotype } & & \\ \text { AA } & 4066 & 76.82 \\ \text { AS } & 1217 & 22.99 \\ \text { SS } & 8 & 0.15 \\ \text { Others } & 0 & 0 \\ \text { Not stated } & 2 & 0.04 \\ \text { Total } & 5293 & 100 \\ \text { Packed cell volume }(\%) & & \\ <25 & 84 & 1.59 \\ 25-27 & 297 & 5.61 \\ 28-30 & 1093 & 20.65 \\ 31-33 & 1818 & 34.35 \\ >33 & 2001 & 37.8 \\ \text { Not stated } & 0 & 0 \\ \text { Total } & 5293 & 100\end{array}$

*ESUTH =Enugu State University Teaching Hospital

Table 3: Results of HIV, VDRLandHBsAg tests in Enugu.

$\begin{array}{lll}\text { Retroviral screening (HIV) } & \text { Number } & \text { Percentage (\%) } \\ \text { Positive } & \text { 232(New 17) } & 4.83 \% \text { (New 0.32\%) } \\ \text { Negative } & 5124 & 96.80 \\ \text { Not stated } & 0 & 0 \\ \text { Total } & 5293 & 100 \\ \text { Veneral Disease Research Laboratory (VDRL) } & \\ \text { Reactive } & 28 & 0.53 \\ \text { Non-Reactive } & 5265 & 99.47 \\ \text { Not stated } & 0 & 0 \\ \text { Total } & 5293 & 100 \\ \text { Hepatitis B Surface Antigen (HBsAg) } & \\ \text { Reactive } & 166 & 3.14 \\ \text { Non-Reactive } & 5127 & 96.86 \\ \text { Not stated } & 0 & 0 \\ & & \end{array}$




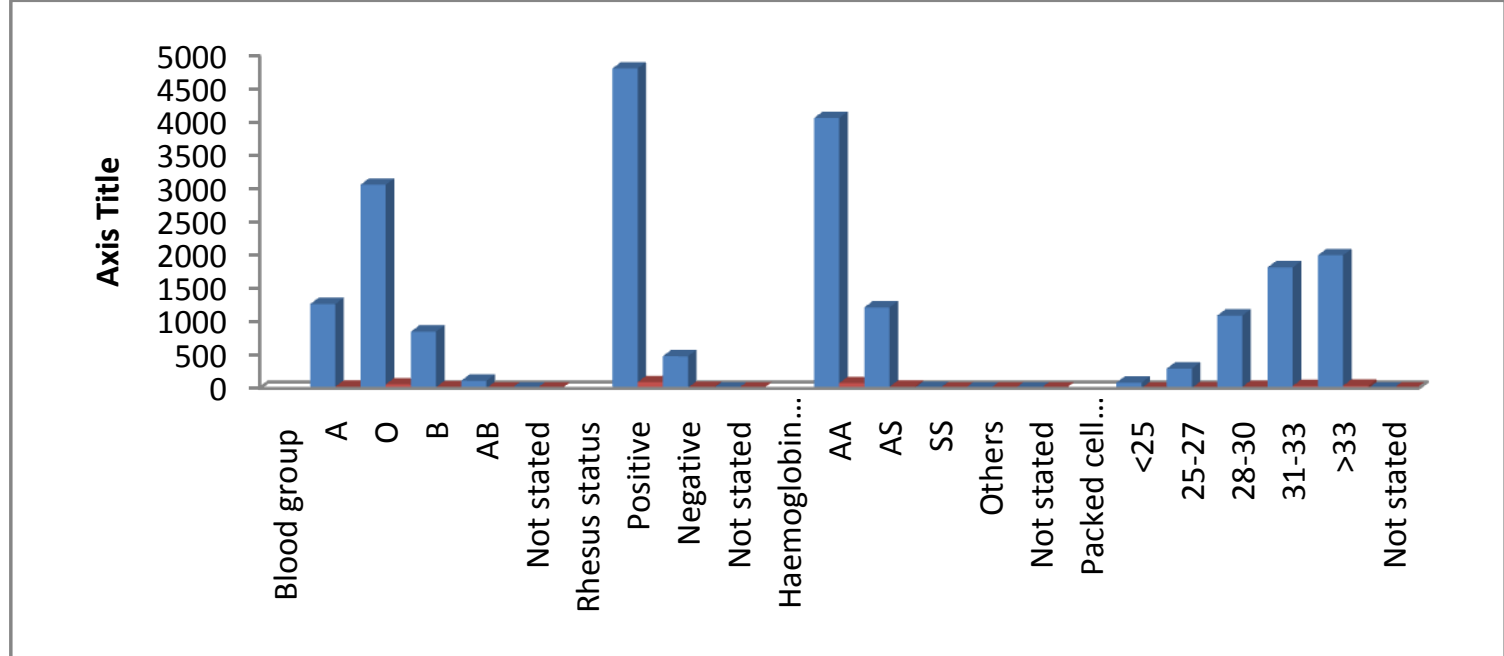

Figure 1: Results of hematological tests at booking antenatal clinic in ESUTH*, Enugu *ESUTH =Enugu State University Teaching Hospital

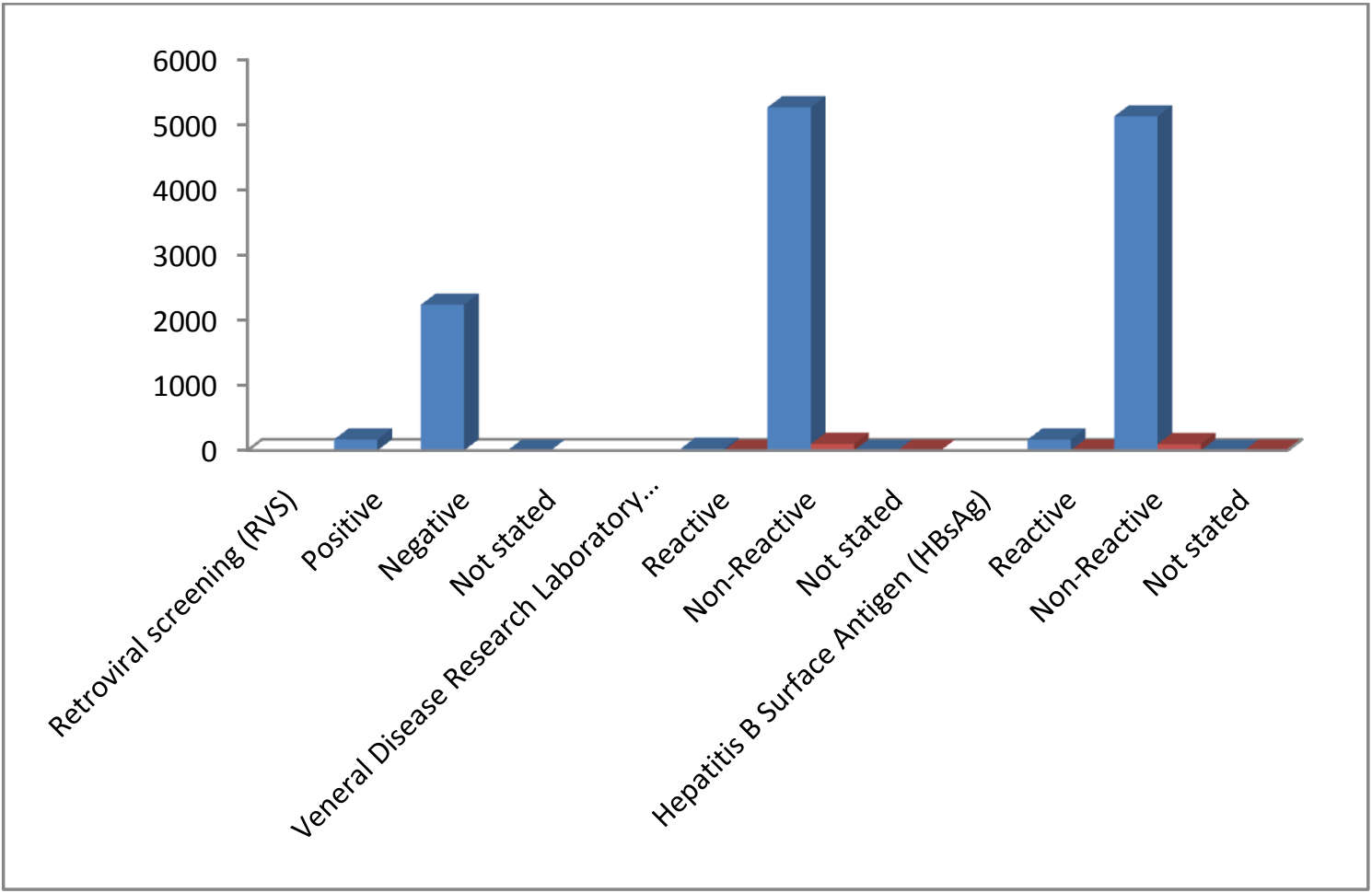

Figure 2: Results of HIV, VDRL and HBsAg tests in ESUTH, Enugu.

\section{REFERENCES}

[1]. Lassiet al (2014). Essential interventions for maternal, newborn and child health: background and methodology. Reproductive Health 2014,11(Suppl 1):S1 http://www.reproductive-healthjournal.com/content/11/S1/S1

[2]. Tunçalp Ö, Were WM, MacLennan C, Oladapo OT, Gülmezoglu AM, Bahl R et al. Quality of care for pregnant women and newborns-the WHO vision. BJOG. 2015;122(8):1045-9.doi:10.1111/14710528.13451.

[3]. Alkema L, Chou D, Hogan D, Zhang S, Moller A-B, Gemmill A et al.; United Nations Maternal Mortality Estimation Inter-Agency Group collaborators and technical advisory group. Global, regional, and national levels and trends in maternal mortality between 1990 and 2015, with scenario-based projections to 2030: a systematic analysis by the UN Maternal Mortality Estimation Inter-Agency Group. Lancet. 2016;387(10017):462-74. doi:10.1016/S0140-6736(15)00838-7. 
Prevalence of Routine Antenatal Laboratory Tests at Booking in Enugu State University of ..

[4]. Maternal mortality. Fact sheet No. 348; Geneva: World Health Organization; 2014 (http://www.who.int/mediacentre/factsheets/fs348/en/index.html, accessed 22 June 2014).

[5]. Integrated Management of Pregnancy and Childbirth (IMPAC). In: Maternal, newborn, child and adolescent health [WHO web page]. Geneva: World Health Organization (http://www.who.int/maternal_child_adolescent/topics/maternal/impac/en/, accessed 17 October 2016).

[6]. Downe S, Finlayson K, Tunçalp Ö, Gülmezoglu AM. What matters to women: a scoping review to identify the processes and outcomes of antenatal care provision that are important to healthy pregnant women. BJOG. 2016;123(4):529-39. doi:10.1111/1471-0528.13819.

[7]. Innocent I. Okafor, Emmanuel O. Ugwu, Samuel N. Obi. Disrespect and abuse during facility-based childbirth in a low-income country. International journal of Gynecology and Obstetrics 128 (2015) 110113.

[8]. WHO. Monitoring emergency obstetric care. [Cited 2013 Sep 24]. Available from: http:// www.who.int/ reproductivehealth/publicat ions / monitoring/9789241547734/en/index.html

[9]. Yakasai IA, Umar U, Ibrahim SA, Abubakar IS (2012). Is Routine Antenatal Screening test for Syphylis Using VDRL Still Relevant? Academic Research International, Vol. 2 No. 2, March 2012. ISSN-L: 22239553, ISSN: 2223-9944

[10]. Betrand O Nwosu, George U Eleje, Amaka L Obi-Nwosu, Ita F Ahiarakwem, Comfort N Akujobi, Chukwudi C Egwuatu et al (2015). Is routine antenatal venereal disease research laboratory test still justified? Nigerian experience. International Journal of Women's Health 2015:7 41-46

[11]. Okafor II, Ugwu EO, Obi SN, Odugu BU (2014). Virtual elimination of motherto-child transmission of human immunodeficiency virus in mothers on highly active antiretroviral therapy in Enugu, SouthEastern Nigeria. Ann Med Health Sci Res 4: 615-618.

[12]. Dim CC1, Ugwu EO, Iloghalu EI (2013). Duration and determinants of interbirth interval among women in Enugu, south-eastern Nigeria. See comment in PubMed Commons below J ObstetGynaecol 33: 175179.

[13]. ZaccheausAwortu Jeremiah (2005). An Assessment of the Clinical Utility of Routine Antenatal Screening of Pregnant Women at First Clinic Attendance for Haemoglobin Genotypes, Haematocrit, $\mathrm{ABO}$ and Rh Blood Groups in PortHarcourt, Nigeria. African Journal of Reproductive Health Vol. 9 No.3 December 2005

[14]. Pramanik KJ, Pramanik S (2000). Distribution of ABO and Rh blood groups in Nepalese Medical Students: a report. Eastern Mediterr Health J. 2000; 6: 156 - 158

[15]. Wagner FF, Kasulke D, Kerowgan M and Flegel WA (1995). Frequencies of the Blood groups, ABO, Rhesus, D. Category VI, Kell and of clinically high frequency antigens in South West Germany. InfusionstherTransfusionmed, 1995; 22: $285-290$.

[16]. Okeke TC, Ocheni S, Nwagha UI, Ibegbulam OG (2012). The prevalence of Rhesus negativity among pregnant women in Enugu, Southeast Nigeria. Niger J ClinPract 2012;15:400-2.

[17]. Erhabor O., KabiruSalisuAdamu, Yakubu A., Shehu C. E., Hassan M., Singh S (2014).

$\mathrm{Rh}$ (D) Phenotype among Pregnant Women in Sokoto, North Western Nigeria.Implications on Haemolytic Disease of the New-Born and Haemolytic Transfusion Reaction.Health Science Research. Vol. 1, No. 2, 2014, pp. 19-24.

[18]. Bowman JM . Maternal alloimmunization and fetal haemolytic disease. In: Reece EA, Hobbins JC, Mahoney MJ, and Petrie PH (eds). Medicine of the fetus and mother. J.B. Lippincott, Philadelphia, 1992; pp. $1152-1154$.

[19]. Ezeilo GC (1970). The influence of post-independence migrations on blood group distribution in Lusaka, Zambia. East Afr Med J 1970;47:686-92.

[20]. Umoh AV, Abah GM, Ekanem TI, Essien EM 9(2010). Haemoglobin genotypes: a prevalence study and implications for reproductive health in Uyo, Nigeria. Niger J Med. 2010 Jan-Mar;19(1):36-41.

[21]. SinouMT(2003). Antenatal Screening of Sickle cell Disease. 8th Postgraduate course for Training in Reproductive Medicine and Reproductive Biology. Cameroon.(Campano A ed.) 2003.

[22]. Nwabuko OC, Okoh DA, Iyalla C, Omunakwe H (2016). Prevalence of sickle cell disease among pregnant women in a tertiary health center in south-south Nigeria. Sub-Saharan Afr J Med 2016;3:132-6.

[23]. Olujimi A. Olatunbosun,1Aniekan M. Abasiattai,1 Emem A. Bassey,1 Robert S. James,1 Godwin Ibanga, 1 and Anyiekere Morgan (2014). Prevalence of Anaemia among Pregnant Women at Booking in the University of Uyo Teaching Hospital, Uyo, Nigeria. BioMed Research International Volume 2014 (2014), Article ID 849080, 8 pages. http://dx.doi.org/10.1155/2014/849080

[24]. CO Agboghoroma, Z Iliyasu. Prevalence and trends among pregnant women in Abuja, Nigeria: a 5-year analysis. Tropical Journal of Obstetrics and Gynaecology>Vol 32, No1 (2015) > 
Prevalence of Routine Antenatal Laboratory Tests at Booking in Enugu State University of ..

[25]. Jeffrey W. Eaton, Thomas M. Rehle, Sean Jooste, Rejoice Nkambule, Andrea A. Kim, Mary Mahy et al (2014). Recent HIV prevalence trends among pregnant women and all women in sub-Saharan Africa: implications for HIV estimates. AIDS 2014, 28 (Suppl 4):S507-S514

[26]. Nigeria National Agency for the Control of AIDS, 2012. Global AIDS Response: Country Progress Report. GARPR, Abuja, Nigeria. Available: <http://www.unaids. org/en/dataanalysis/knowyourresponse/countryprogressreports/2012 countries/ Nigeria\%202012\% GARPR\%20Report\%20Revised.pdf > (accessed 7 February 2013).

[27]. WHO (2012). Use of antiretroviral drugs for treating pregnant women and preventing HIV infection in infants: Programmatic update. Geneva: WHO; 2012. Available from: http://www.who.int/hiv/pub/mtct/programmatic_update2012/en/index.html. [Last accessed on 2012 Jul $11]$.

[28]. Okafor II, Ugwu EO, Obi SN, Odugu BU (2014). Virtual elimination of mother-to-child transmission of human immunodeficiency virus in mothers on highly active antiretroviral therapy in Enugu,South-Eastern Nigeria. Ann Med Health Sci Res 2014;4:615-8.

[29]. Frickmann H, Schwarz NG, Girmann M, et al.(2013) Serological survey of HIV and syphilis in pregnant women in Madagascar. Trop Med Int Health. 2013;18:35-39.

[30]. World Health Organisation. Guidelines for the management of sexually transmitted infection. 2001. WHO, Geneva

[31]. Osoba AO (1972). Serological test for syphilis among hospital patients in Ibadan, 1968-1970. Proceedings of the first medical research seminar, Fifty years of medical research in Nigeria, 1-4 February 1972. Yaba, Lagos: Academic Press; 1972:49-52.

[32]. Ekele BA, Bello CSS (1997). Sero-reactivity amongst pregnant women screened for syphilis at Jos University Teaching Hospital. Niger J Med. 1997;6:11-13.

[33]. Bukar M, Audu BM, Takai UI, Ajayi BB, Kullima AA (2009). Is routine antenatal screening for syphilis in Nigeria still justified clinically and economically? Saudi Med J. 2009;30:1311-1315.

[34]. Hira S, Ratnam A, Bhat G, et al. (1982) Congenital syphilis in Lusaka-II. Incidence at birth and potential risks among hospital delivered infants. East Afr Med J. 1982;59:306-308.

[35]. Azeze B, Fantahun M, Kidan KG, Haile T (1995). Seroprevalence of syphilis among pregnant women attending antenatal clinics in a rural hospital in north west Ethiopia. Genitourin Med. 1995;71:347-350.

[36]. Hira SK, Bhat GJ, Chikamata DM (1990). Syphilis intervention in pregnancy: Zambian demonstration project. Genitourin Med. 1990;66:159-164.

[37]. Lurman A. Eine icterus Epidemic. Berlin KlinWochenschr. 1855;22:20-23.

[38]. Global, regional, and national age-sex specific all-cause and cause-specific mortality for 240 causes of death, 1990-2013: a systematic analysis for the Global Burden of Disease Study 2013 GBD 2013 Mortality and Causes of Death Collaborators. Lancet. 2015;385(9963):117-71.

[39]. McMahon BJ, Alward WL, Hall DB, et al.(1985) Acute hepatitis B virus infection: relation of age to the clinical expression of disease and subsequent development of the carrier state. J Infect Dis 1985;151:599-603 .

[40]. Edmunds WJ, Medley GF, Nokes DJ, Hall AJ, Whittle HC (1993). The influence of age on the development of the hepatitis B carrier state. ProcBiolSci 1993;253:197--201.

[41]. Hyams KC (1995). Risks of chronicity following acute hepatitis B virus infection: a review. Clin Infect Dis 1995;20:992--1000.

[42]. Hadler SC, Judson FN, O'Malley PM, et al. (1991) Outcome of hepatitis B virus infection in homosexual men and its relation to prior human immunodeficiency virus infection. J Infect Dis 1991;163:454--9.

[43]. Baruch S. Blumberg - Autobiography." Nobel Prize". Nobelprize.org. Archived from the original on 29 April 2011. Retrieved 2011-04-07

[44]. Blumberg, B. S., B. J. Gerstley, D. A. Hungerford, W. T. London, and A. I. Sutnick (1967). A serum antigen (Australia antigen) in Down's syndrome, leukemia, and hepatitis. Ann. Intern. Med. 66:924-931.

[45]. Kramvis A, Kew MC (2007). Epidemiology of hepatitis B virus in Africa, its genotypes and clinical associations of genotypes. Hepatol Res 2007; 37: S9-S19 [PMID: 17627641 DOI: 10.1111/j.1872034X.2007.00098.x]

[46]. Musa B, Bussell S, Borodo M M, Samaila A A, Femi O L(2015). Prevalence of hepatitis B virus infection in Nigeria, 2000-2013: A systematic review and meta-analysis. Niger J ClinPract 2015;18:16372

[47]. FI Buseri, E Seiyaboh, and ZA Jeremiah (2010). Surveying Infections among Pregnant Women in the Niger Delta, Nigeria. J Glob Infect Dis. 2010 Sep-Dec; 2(3): 203-211. doi: 10.4103/0974-777X.68525 PMCID: PMC2946673

[48]. Utoo BT (2013). Hepatitis B surface antigenemia (HBsAg) among pregnant women in southern Nigeria. African Health Sciences 2013; 13(4): 1139 - 1143 http://dx.doi.org/10.4314/ahs.v13i4.39 